\title{
Pranayama a Neuro-Physiological Explanation of the Mechanism
}

\author{
Vidyasagar Casikar* \\ Consultant Neurosurgeon, Australia
}

Submission: July 05, 2017; Published: July 13, 2017

*Corresponding author: Vidyasagar Casikar, Consultant Neurosurgeon, Australia, Tel: (02)-4735-8583; Fax: (02)-4735-8552;

Email: vcasikar2007@gmail.com

\section{Opinion}

Yoga is an ancient Indian way of life which includes changes in mental attitude, diet and practice of specific techniques (Asanas), breathing practices (Pranayama) and medication to obtain highest level of consciousness. Pranayama or regulated breathing is considered as one of the essential aspects of Yoga. When a person breathes the olfactory nerves situated in the roof of the nose are stimulated. This is transferred onto the olfactory bulbs which are located at the base of the skull in the region of the cribriform plate. This olfactory bundle is connected to the median frontal bundle which is located in the midline in the front of the brain. This in turn is connected to the hypothalamus. The hypothalamus regulates hormones. In any stress, the serotonin receptors in the hypothalamus through the splanchnic pathway regulates the stress. This mechanism is independent of ACTH-cortisol feedback system. When there is a disruption of the regular breathing there usually occurs a face locking of the olfactory signals and the hypothalamus does not receive appropriate signals. This face locking of the olfactory bulb causes disorganised information to the hypothalamus and there are consequences due to hypothalamus pituitary adrenal dysfunction.

The author was interested in the high-altitude stress otherwise known as acute mountain sickness. As the altitude increases there is reduced oxygen and this leads to rapid breathing. The author and his team postulated that this may be a basis for high altitude hypoxic dysfunction. To examine this hypothesis further laboratory rats whose olfactory bulbs were stereotacticallly destroyed were subjected to high altitude conditions in the laboratory. Rats whose olfactory bulbs were intact were used as controls [1]. The experiments indicated that the rats with olfactory bulb lesions suffered loss of body weight, increase in the levels of blood urea, decrease in the LDH in liver and kidney and a drop in the STH in the liver and kidney. The levels of protein in the kidney and liver also increased. The serum creatinine and calcium levels also increased significantly. Normally, rats are not known to suffer from acute mountain sickness because they are able to regulate their hypothalamic function by assessing the atmospheric oxygen content saturation and temperature. When this mechanism is lost they suffer from high altitude acute mountain sickness. This is a stress adaptation failure. The weight loss is due to the post-operative stress of hypoxia and conditions simulated in high altitude. The increase in serum levels is probably due to shivering which results in increased adrenal hormonal function, both medullary and cortical. This suggests a probable hypothalamus splanchnic pathway dysfunction.

The reduced LDH levels in the liver is difficult to explain. It is possible that this is ACTH cortisol feedback mechanism or a serotonergic response. The significant reduction of STH levels in the kidney and liver suggests a mitochondrial dysfunction. Mitochondrial function is dependent on the oxygen levels in the blood. Hypoxia, which is part of the high-altitude stress is responsible for these changes. Increase in the serum calcium level is an indicator of a psychogenic stress. There is a delicate balance between the respiratory cycle and the olfactory neurons. It has been shown that irregularities of respiratory rhythm induces face locking of the mitral cells of the olfactory bulb. The temporal and spatial organisations of the responses are influenced by frequency, variability of the sniffing responses in the rats [2]. These respiratory oscillations of the mitral cells are influenced by a glutamate receptor function. These experiments postulate that the respiratory function as a modulator of olfactory limbic hypothalamus structures. They could also be a limbic oriented memory function during the periods of face matching between the olfactory and limbic hypothalamus structures.

The high-altitude condition is an extreme example of acute stress. It is possible that regular breathing (Pranayama) reduces the possibility or the intensity of high altitude stress 
related issues. The same argument can be perhaps used to explain the normal stress related conditions that occur in our everyday life. Pranayama probably reduces reactions due to stress. This observation is based mainly on the experimental findings which we have indicated above. Actual studies of these functions with reference to breathing on human subjects are not available, though there are many speculations about its regulating mechanism. Various topics on Yoga indicate that the regular breathing has beneficial effects. It is postulated that the parasympathetic nervous system allows to recoup from the stresses of life. However, these authors do not actually indicate the relationship between the breathing and the various advantages in the human physiology. The experiments conducted by these authors have tried to establish a verifiable evidence of the mechanism of Pranayama. Some of the benefits claimed by the Yogi practice could be extrapolated to the findings of our experiments. More structured controlled assessment of the breathing practice on bodily functions need further evaluation.

\section{References}

1. Nagabhushana S, Venkatesh T, Casikar V (2011) The olfactory system regulates acute mountain sickness. Journal of stress physiology \& biochemistry 5(1-2): 4-15.

2. Kashwadani H, Sasaki YF, Uchida N, Mori K (1999) Synchronized Oscillatory Discharges of Mitral/Tufted cells with Different Molecular Receptive Ranges in the Rabbit Olfactory Bulb. Jr Neurophysiology 82(4): 1786-1792.

\section{Your next submission with Juniper Publishers will reach you the below assets}

- Quality Editorial service

- Swift Peer Review

- Reprints availability

- E-prints Service

- Manuscript Podcast for convenient understanding

- Global attainment for your research

- Manuscript accessibility in different formats ( Pdf, E-pub, Full Text, Audio)

- Unceasing customer service

Track the below URL for one-step submission https://juniperpublishers.com/online-submission.php 